\title{
PROFIL PENGGUNAAN OBAT ANTIHIPERTENSI PADA PERIODE SEPTEMBER 2019 SAMPAI DENGAN SEPTEMBER 2020 DI RSUD KOTA PINANG
}

\author{
Ovalina Sylvia Br. Ginting ${ }^{1 *}$, Khairinah Pasaribu² \\ ${ }^{1,2}$ Program Studi Farmasi, Fakultas Ilmu Kesehatan, Universitas Haji Sumatera Utara \\ Medan, Indonesia \\ Email: ovalinasylviabr.ginting@gmail.com \\ * corresponding author
}

\begin{abstract}
Abstrak
Hipertensi masih menjadi penyakit kardiovaskular yang sampai saat ini prevalensinya diperkirakan terus bertambah di seluruh dunia. Hipertensi perlu mendapat perhatian khususnya dalam sistem pelayanan kesehatan dibidang farmasi dengan menjamin tersedianya obat-obatan. Tujuan penelitian ini adalah untuk mengetahui presentase Obat Antihipertensi pada Periode September 2019 sampai dengan September 2020 di RSUD Kota Pinang. Penelitian ini merupakan penelitian restrospektif. Populasi dalam penelitian ini adalah seluruh pasien hipertensi yang berobat di RSUD Kota Pinang pada periode Bulan September 2019 sampai dengan September 2020 sebanyak 492 orang berdasarkan data rekam medik di RSUD Kota Pinang. Pengambilan sampel menggunakan Simple Rando sampling sebanyak 83 orang. Obat antihipertensi adalah obat-obatan yang digunakan untuk mengobati hipertensi di RSUD Kota Pinang seperti candesartan 8 mg, candesartan $16 \mathrm{mg}$, Amlodipine $5 \mathrm{mg}$, Amlodipine $10 \mathrm{mg}$, Lisinopril $5 \mathrm{mg}$, Lisinopril $10 \mathrm{mg}$, captopril 12,5 mg dan Captopril $25 \mathrm{mg}$. Berdasarkan hasil penelitian didapatkan bahwa Profil Pasien di RSUD Kota Pinang adalah sebagian besar umur 61-70 Tahun, jenis kelamin sebagian besar perempuan, jenis perawatan sebagian besar adalah rawat jalan dan klasifikasi hipertensi sebagaian besar adalah sedang, Jenis Obat Antihipertensi yang digunakan di RSUD Kota Pinang Periode September 2019 sampai dengan September 2020 adalah candesartan 8 mg, candesartan 16 $\mathrm{mg}$, Amlodipine $5 \mathrm{mg}$, Amlodipine $10 \mathrm{mg}$, Lisinopril $5 \mathrm{mg}$, Lisinopril $10 \mathrm{mg}$, captopril 12,5 mg dan Captopril $25 \mathrm{mg}$ dan Presentase Obat Antihipertensi yang sering diresepkan pada Periode September 2019 sampai dengan September 2020 adalah Amlodipine $10 \mathrm{mg}$. Saran dalam penelitian diharapkan menjadi referensi awal dalam melanjutkan penelitian yang sama serta menambah variabel penelitian agar penelitian tersebut dapat semakin akurat.
\end{abstract}

Kata kunci: Hipertensi, Pasien Hipertensi, Obat Antihipertensi

\begin{abstract}
Hypertension is still a cardiovascular disease whose prevalence is estimated to continue to increase worldwide. Hypertension needs to get attention, especially in the health service system in the pharmaceutical sector by ensuring the availability of drugs. The purpose of this study was to determine the percentage of antihypertensive drugs in the period September 2019 to September 2020 at the Kota Pinang Hospital. This study is a retrospective study. The population in this study were 492 hypertensive patients who were treated at the Kota Pinang Hospital in the period
\end{abstract}


September 2019 to September 2020 based on medical record data at the Kota Pinang Hospital. Sampling using Simple Commando sampling as many as 83 people. Antihypertensive drugs are drugs used to treat hypertension at the Pinang City Hospital such as candesartan $8 \mathrm{mg}$, candesartan $16 \mathrm{mg}$, Amlodipine $5 \mathrm{mg}$, Amlodipine $10 \mathrm{mg}$, Lisinopril $5 \mathrm{mg}$, Lisinopril $10 \mathrm{mg}$, captopril $12.5 \mathrm{mg}$ and Captopril $25 \mathrm{mg}$. Based on the results of the study, it was found that the Patient Profiles at Kota Pinang Hospital were mostly 61-70 years old, the sex was mostly female, most of the types of treatment were outpatient and the classification of hypertension was mostly moderate, the type of antihypertensive drugs used in RSUD Kota Pinang. The period from September 2019 to September 2020 is candesartan $8 \mathrm{mg}$, candesartan $16 \mathrm{mg}$, Amlodipine $5 \mathrm{mg}$, Amlodipine $10 \mathrm{mg}$, Lisinopril $5 \mathrm{mg}$, Lisinopril $10 \mathrm{mg}$, captopril $12.5 \mathrm{mg}$ and Captopril $25 \mathrm{mg}$ and the percentage of antihypertensive drugs that are often prescribed in this period. September 2019 to September 2020 is Amlodipine $10 \mathrm{mg}$. Suggestions in research are expected to be an initial reference in continuing the same research and adding research variables so that the research can be more accurate.

Keywords: Hypertension, Hypertensive Patients, Antihypertensive drugs

\section{Pendahuluan}

Hipertensi masih menjadi penyakit kardiovaskular yang sampai saat ini prevalensinya diperkirakan terus bertambah di seluruh dunia. Pada tahun 2025, penderita hipertensi diperkirakan akan mencapai 60\% populasi dunia (Saepudin dkk, 2013). Hipertensi dapat mengakibatkan kerusakan berbagai organ seperti otak, jantung, ginjal, aorta, pembuluh darah perifer, dan retina (Rachman dan Kaelan, 2014). Hipertensi perlu mendapat perhatian khususnya dalam sistem pelayanan kesehatan dibidang farmasi dengan menjamin tersedianya obat-obatan (Alaydrus, 2017). Obat-obat antihipertensi yang ada saat ini telah terbukti dapat mengontrol tekanan darah pada pasien hipertensi (Saepudin dkk, 2013). Terapi hipertensi dengan obat antihipertensi merupakan salah satu upaya untuk menurunkan tekanan darah pasien. Tujuan pengobatan hipertensi adalah untuk mencegah terjadinya morbiditas dan mortalitas akibat tekanan darah tinggi dengan menurunkan tekanan darah serendah mungkin sampai tidak mengganggu fungsi ginjal, otak, jantung, maupun kualitas hidup, sambil dilakukan pengendalian faktor-faktor resiko kardiovaskuler lainnya (Tyashapsari dan Zulkarnain, 2012).

Berdasarkan survei awal yang dilakukan di RSUD Kota Pinang bahwa angka kejadian hipertensi pada tahun 2018 sebanyak 480 orang yang berobat ke RSUD Kota Pinang. Pada periode bulan September 2019 sampai dengan bulan September 2020 didapatkan data bahwa rata-rata pasien yang berkunjung dengan masalah kesehatan hipertensi sebanyak 41 orang dengan total jumlah pasien hipertensi sebanyak 492 orang pasien. Berdasarkan data obat antihipertensi yang tersedia di RSUD Kota Pinang adalah adalah candesartan $8 \mathrm{mg}$, candesartan $16 \mathrm{mg}$, Amlodipine $5 \mathrm{mg}$, Amlodipine $10 \mathrm{mg}$, Lisinopril $5 \mathrm{mg}$, Lisinopril $10 \mathrm{mg}$, captopril 12,5 mg dan Captopril $25 \mathrm{mg}$. Obat antihipertensi yang paling sering diresepkan di RSUD Kota Pinang adalah Amlodipine 10 mg dan candesartan $8 \mathrm{mg}$ (Profil RSUD Kota Pinag, 2020). Berdasarkan permasalahan diatas peneliti tertarik ingin melakukan penelitian tentang "Profil Penggunaan Obat Antihipertensi pada Periode September 2019 sampai dengan September 2020 di RSUD Kota Pinang".

\section{Metode Penelitian}

Jenis penelitian ini merupakan penelitian restrospektif yaitu penelitian yang dimaksudkan untuk menggambarkan keadaan, kondisi atau hal-hal lain yang hasilnya 
dipaparkan dalam bentuk laporan penelitian yang sudah terjadi sebelumnya untuk mengetahui Profil Penggunaan Obat Antihipertensi pada Periode September 2019 sampai dengan September 2020 di RSUD Kota Pinang.. Teknik pengambilan sampel menggunakan Simple Rando sampling dengan banyak sampel sebanyak 83 orang. Penelitian ini telah dilaksanakan dengan dari periode Februari sampai dengan April 2021. Populasi dalam penelitian ini adalah seluruh pasien hipertensi yang berobat di RSUD Kota Pinang pada periode Bulan September 2019 sampai dengan September 2020 sebanyak 492 orang berdasarkan data rekam medik di RSUD Kota Pinang. Data yang digunakan adalah data sekunder yaitu data yang diperoleh dari dari rekam medik pasien dengan hipertensi yang berobat di RSUD Kota Pinang berdasarkan jenis obat antihipertensi meliputi, jenis kelamin, usia dan obat antihipertensi yang digunakan. Data yang diperoleh dianalisis secara deskriptif untuk mengetahui Profil Penggunaan Obat Antihipertensi pada Periode September 2019 sampai dengan September 2020 di RSUD Kota Pinang yang meliputi jenis Obat, dosis, dan kombinasi obat antihipertensi pada pasien hipertensi.

\section{Hasil dan Pembahasan}

Berdasarkan penelitian yang telah dilakukan, maka didapatkan hasil sebagai berikut.

Tabel 1. Profil Pasien berdasarkan Umur Responden

\begin{tabular}{clcc}
\hline No & Umur Responden & Frekuensi (f) & Persentase (\%) \\
\hline 1 & $\leq 40$ Tahun & 1 & 1,2 \\
2 & 41-50 Tahun & 11 & 13,3 \\
3 & 51-60 Tahun & 26 & 31,3 \\
4 & 61-70 Tahun & 39 & 47,0 \\
5 & $\geq 71$ Tahun & 6 & 7,2 \\
\hline & Jumlah & $\mathbf{8 3}$ & $\mathbf{1 0 0 , 0}$ \\
\hline
\end{tabular}

Berdasarkan tabel di atas dapat dilihat bahwa dari 83 orang responden sebagian besar usia responden adalah usia 61-70 Tahun sebanyak 39 orang (57\%).

Tabel 2. Profil Pasien berdasarkan Umur

\begin{tabular}{cllcc}
\hline No & & Jenis Kelamin & Frekuensi (f) & Persentase (\%) \\
\hline 1 & Laki-Laki & 39 & 47,0 \\
2 & Perempuan & 44 & 53,0 \\
\hline & Jumlah & $\mathbf{8 3}$ & $\mathbf{1 0 0 , 0}$ \\
\hline
\end{tabular}

Berdasarkan tabel di atas bahwa dari 83 orang responden sebagian besar jenis kelamin responden adalah perempuan sebanyak 44 orang $(53 \%)$. 
Tabel 3. Profil Pasien berdasarkan Perawatan Pasien

\begin{tabular}{clccc}
\hline No & & Perawatan & Frekuensi (f) & Persentase (\%) \\
\hline 1 & Rawat Inap & 21 & 25,3 \\
2 & Rawat Jalan & 62 & 74,7 \\
\hline & Jumlah & $\mathbf{8 3}$ & $\mathbf{1 0 0 , 0}$ \\
\hline
\end{tabular}

Berdasarkan tabel di atas dilihat bahwa dari 83 orang responden sebagian besar adalah pasien rawat jalan sebanyak 62 orangg (74,7\%). Artinya pasien sebagian besar merupakan pasien berulang berkunjung ke RSUD Kota Pinang untuk mendapatkan obat antihipertensi.

Tabel 4. Profil Pasien berdasarkan Klasifikasi Hipertensi

\begin{tabular}{clcc}
\hline No & \multicolumn{1}{c}{ Klasifikasi Hipertensi } & $\begin{array}{c}\text { Frekuensi } \\
\text { (f) }\end{array}$ & $\begin{array}{c}\text { Persentase } \\
(\mathbf{\%})\end{array}$ \\
\hline 1 & Stadium 1 (Ringan) (140-159/80-89 mmHg & 24 & 28,9 \\
2 & Stadium 2 (Sedang) $(160-179 / 100-109 \mathrm{mmHG}$ & 51 & 61,4 \\
3 & Stadium 3 (Berat) (180-209/110-119 mmHG) & 8 & 9,6 \\
\hline & Jumlah & $\mathbf{8 3}$ & $\mathbf{1 0 0 , 0}$ \\
\hline
\end{tabular}

Berdasarkan tabel di atas dapat dilihat bahwa dari 83 orang responden sebagian besar klasifikasi hipertensi pasien adalah stadium 2 (sedang) dengan rentang sistolik dan diastolik adalah 160-179/100-109 mmHG sebanyak 51 orang $(61,4 \%)$.

Tabel 5. Jenis Obat Antihipertensi yang digunakan di RSUD Kota Pinang Periode September 2019 sampai dengan September 2020

\begin{tabular}{ll}
\hline No & \\
\hline 1 & Nama Obat \\
\hline 2 & Candesartan $8 \mathrm{mg}$ \\
\hline 3 & Amlodipine $5 \mathrm{mg}$ \\
\hline 4 & Amlodipine $10 \mathrm{mg}$ \\
\hline 5 & Lisinopril $5 \mathrm{mg}$ \\
\hline 6 & Lisinopril $10 \mathrm{mg}$ \\
\hline 7 & captopril $12,5 \mathrm{mg}$ \\
\hline 8 & captopril $25 \mathrm{mg}$ \\
\hline
\end{tabular}

Berdasarkan tabel di atas dapat dilihat obat antihipertensi yang tersedia di RSUD Kota Pinang adalah candesartan $8 \mathrm{mg}$, candesartan $16 \mathrm{mg}$, Amlodipine $5 \mathrm{mg}$, Amlodipine 10 $\mathrm{mg}$, Lisinopril $5 \mathrm{mg}$, Lisinopril $10 \mathrm{mg}$, captopril 12,5 mg dan Captopril $25 \mathrm{mg}$. 
Tabel 6. Presentase Obat Antihipertensi pada Periode September 2019 sampai dengan September 2020 di RSUD Kota Pinang

\begin{tabular}{llcc}
\hline No & \multicolumn{1}{c}{ Profil Obat Antihipertensi } & Frekuensi (f) & Persentase (\%) \\
\hline 1 & Candesartan $8 \mathrm{mg}$ & $\mathbf{1 7}$ & $\mathbf{2 0 , 5}$ \\
2 & Candesartan $16 \mathrm{mg}$ & 13 & 15,7 \\
3 & Amlodipine $5 \mathrm{~g}$ & 7 & 8,4 \\
4 & Amlodipine $10 \mathrm{mg}$ & 19 & 22,9 \\
5 & Lisinopril $5 \mathrm{mg}$ & 7 & 8,4 \\
6 & Lisinopril $10 \mathrm{mg}$ & 5 & 6,0 \\
7 & Captopril 12,5 & 10 & 12,0 \\
8 & Captopril $25 \mathrm{mg}$ & 5 & 6,0 \\
\hline & Jumlah & $\mathbf{8 3}$ & $\mathbf{1 0 0 , 0}$ \\
\hline
\end{tabular}

Berdasarkan di atas dari 83 orang responden dapat dilihat bahwa sebagian besar obat antihipertensi yang sering diresepkan adalah Amlodipine $10 \mathrm{mg}$ sebanyak 19 orang $(22,9 \%)$.

\section{Kesimpulan}

Berdasarkan penelitian yang dilakukan di Puskesmas Tangkahan Durian dapat disimpulkan bahwa profil Pasien di RSUD Kota Pinang adalah sebagian besar umur 6170 tahun, jenis kelamin sebagian besar perempuan, jenis perawatan sebagian besar adalah rawat jalan dan klasifikasi hipertensi sebagaian besar adalah sedang. Obat Antihipertensi yang digunakan di RSUD Kota Pinang Periode September 2019 sampai dengan September 2020 adalah candesartan $8 \mathrm{mg}$, candesartan $16 \mathrm{mg}$, Amlodipine $5 \mathrm{mg}$, Amlodipine $10 \mathrm{mg}$, Lisinopril $5 \mathrm{mg}$, Lisinopril $10 \mathrm{mg}$, captopril 12,5 mg dan Captopril 25 mg. dan presentase Obat Antihipertensi yang sering diresepkan pada Periode September 2019 sampai dengan September 2020 adalah Amlodipine 10 mg.

\section{Referensi}

Alaydrus, S. (2017). Profil Penggunaan Obat pada Pasien Hipertensi di Puskesmas Marawola Periode Januari-Maret 2017. Jurnal Mandala Pharmacon Indonesia. Volume 3. Nomor 2.

Kementerian Kesehatan RI. (2019). Laporan Riskesdas 2018. Jakarta: Badan Litbangkes Profil RSUD Kota Pinang. (2020). Kota Pinang.

Rachman, M,E, Kaelan, Cahyono. (2014). Analisis Perbandingan Obat Antihipertensi (OHT) dengan Kejadian Pola Tekanan Darah Nondippers pada Penderita Hipertensi tanpa Stroke Iskemik. Jurnal As-Syifaa. Volume 06. Hal. 8-16. ISSN : 2085-4714

Saepudin, Padmasari, S, Hidayanti, P dan Ningish, E. (2013). Kepatuhan Penggunaan Obat pada Pasien Hipertensi di Puskesmas. Jurnal Farmasi Indonesia. Volume 6. Nomor 4.

Tyashapsari M, Zulkarnain A. (2012). Penggunaan Obat Pada Pasien Hipertensi Di Instalasi Rawat Ianp Rumah Sakit Umum Pusat Dr. Kariadi Semarang. J Clin Hypertens. 